\title{
Bezpieczeństwo Polski - wymiar globalny, regionalny oraz krajowy. Wybrane zagadnienia
}

\section{Polish security - global, regional and national aspect. Selected problems}

\begin{abstract}
Streszczenie:
Niniejszy artykuł odnosi się do Strategii Bezpieczeństwa Narodowego Rzeczypospolitej Polskiej z 2014 r. Jest ona dokumentem dość obszernym, ponieważ liczy 57 stron. Strategia podzielona została na cztery rozdziały, natomiast artykuł dotyczy rozdziału II zatytułowanego Środowisko bezpieczeństwa Polski. Artykuł nakreśla trzy wymiary bezpieczeństwa Polski - globalny, regionalny oraz krajowy. W końcowej części autorka podsumowuje temat oraz wskazuje cechy charakterystyczne strategii z $2014 \mathrm{r}$.
\end{abstract}

Słowa kluczowe: bezpieczeństwo, globalizacja, Unia Europejska, terroryzm

\begin{abstract}
:
This article refers to Polish National Security Strategy of 2014. This document has 57 pages, so it is quite long. It has 4 chapters but this article refers to chapter 2 - Poland's security environment. This article also describes three aspects of Poland's security global, regional and national. In the summary the author sums up the subject and mentions the main features of the strategy of 2014.
\end{abstract}

Keywords: security, globalization, European Union, terrorism 
Justyna Adamczyk - Bezpieczeństwo Polski...

\section{Wprowadzenie}

Artykuł jest kontynuacją rozważań naukowych z konferencji Strategia Bezpieczeństwa Narodowego w sytuacji zagrożenia - implikacje praktyczne do współpracy samorządów, społeczeństwa, służb mundurowych, która odbyła się we Włocławku 10 maja 2018 r. Temat został podzielony przez autorkę na trzy główne zagadnienia odnoszące się do bezpieczeństwa Polski w kontekście Strategii Bezpieczeństwa Narodowego Rzeczypospolitej Polskiej z 2014 r. Zagadnieniami tymi są: wymiar globalny bezpieczeństwa Polski, wymiar regionalny oraz wymiar krajowy. We wstępie autorka chciałaby wskazać, iż Strategia Bezpieczeństwa Narodowego Rzeczypospolitej Polskiej z 2014 r. uwzględnia szerszą listę zagrożeń dla bezpieczeństwa Polski, lecz $\mathrm{z}$ uwagi na ograniczenia związane z czasem wystąpienia podczas konferencji oraz z objętością tekstu autorka zwróciła uwagę na zagadnienia wybrane przez nią poniżej.

\section{Wymiar globalny bezpieczeństwa Polski}

Strategia Bezpieczeństwa Narodowego Rzeczypospolitej Polskiej z 2014 r. zawiera 9 punktów odnoszących się do tego zagadnienia, usytuowanych w rozdziale II zatytułowanym Środowisko bezpieczeństwa Polski. W pierwszej kolejności autorka chciałaby jednak odnieść się do wstępu umieszczonego na początku rozdziału II Strategii Bezpieczeństwa Narodowego Rzeczypospolitej Polskiej z 2014 r. We wstępie tym zwraca się uwagę na rolę globalizacji we współczesnym świecie oraz na jej wpływ na kształtowanie się bezpieczeństwa. Zwraca się także uwagę na zanikanie granic pomiędzy różnymi wymiarami bezpieczeństwa, takimi jak wymiar wewnętrzny oraz zewnętrzny czy wymiar militarny oraz pozamilitarny. Wymienione są czynniki, od których uzależnione będzie bezpieczeństwo Polski. Pośród tych czynników wymieniono: efektywną realizację interesów narodowych, realizację celów strategicznych obecnie oraz realizację celów strategicznych w przyszłości. Co więcej, poruszona została kwestia wyzwań, 
jakim sprostać będzie musiała Polska, wśród których znajdują się wyzwania typu wewnętrznego oraz zewnętrznego, wyzwania asymetryczne i wyzwania transsektorowe. Wymienione wyzwania stanowią następstwo wpływających na siebie nawzajem procesów związanych z różnymi dziedzinami, to znaczy z polityką, obronnością, ekonomią, demografią czy środowiskiem 1 .

W tym miejscu autorka chciałaby przejść do opisu wybranych punktów ze strategii z 2014 r., odnoszących się do wymiaru globalnego bezpieczeństwa Polski. W pierwszej kolejności zawraca się uwagę na globalizację oraz ryzyko powstania konfliktów o zasięgu regionalnym czy lokalnym. Następnie wymieniona zostaje organizacja międzynarodowa, dbająca o bezpieczeństwo o zasięgu globalnym, czyli Organizacja Narodów Zjednoczonych (ONZ, ang. United Nations). Negatywnymi zjawiskami związanymi z funkcjonowaniem ONZ są: współzawodnictwo państw-członków tej organizacji, mniej efektywne działania oraz osłabnięcie jej autorytetu. Strategia z 2014 r. wskazuje, iż istotną kwestią jest poprawa wizerunku Organizacji Narodów Zjednoczonych, która pomoże w podejmowaniu skutecznych działań w zakresie bezpieczeństwa globalnego. Kolejny problem odnoszący się do bezpieczeństwa globalnego dotyczy osłabnięcia pozycji porozumień rozbrojeniowych, które regulują między innymi zakaz rozprzestrzeniania broni masowego rażenia. Powiązane jest to z ryzykiem rozwoju tego typu broni, z powstaniem kolejnego wyścigu zbrojeń oraz z przejęciem wspomnianej powyżej broni przez terrorystów ${ }^{2}$.

Istotnym zagrożeniem dla bezpieczeństwa o zasięgu globalnym są również porządki autorytarne oraz powiązany z nimi brak respektu dla norm prawa międzynarodowego, ustroju demokracji, praw człowieka oraz mniejszości kulturowych. Należy zwrócić uwagę na to, że wybrane państwa autorytarne posiadają modele gospodarcze będące konkurencją dla ustroju demokracji oraz gospodarki rynkowej. $\mathrm{Na}$

\footnotetext{
1 Strategia Bezpieczeństwa Narodowego Rzeczypospolitej Polskiej z 2014 r., Warszawa 2014, s. 17.

2 Ibidem, s. 17-18.
} 
Justyna Adamczyk - Bezpieczeństwo Polski...

społeczności międzynarodowej spoczywa odpowiedzialność za upowszechnianie ustroju demokratycznego oraz za upowszechnianie takich idei jak praworządność. Strategia z 2014 r. wskazuje przy zagadnieniu porządków autorytarnych transformację ustroju w Polsce, podkreślając, iż stanowi ona przykład dla innych państw chcących przekształcić swój system³.

Kolejnym zagadnieniem wartym omówienia w kontekście globalnego bezpieczeństwa jest terroryzm oraz zorganizowana przestępczość. Terroryzm oraz zorganizowana przestępczość wpływają negatywnie na sytuację wewnętrzną państw oraz rodzą patologie, pośród których znajdują się, na przykład: przemyt broni, handel narkotykami, handel ludźmi, nielegalne transakcje finansowe, uprowadzenia. W tym samym akapicie, w którym wskazane zostały terroryzm oraz zorganizowana przestępczość, wymienia się również migracje ludności, które spowodowane mogą być konfliktami oraz złą sytuacją gospodarczą czy społeczną w danym państwie ${ }^{4}$.

Autorka uważa, że należy opisać pokrótce zagrożenia związane z rozwojem nowych technologii - cyberterroryzm, cyberprzestępczość, cyberkonflikty oraz cyberwojnę. Cyberwojna oznacza, iż spory pomiędzy państwami z ich terytoriów przeniosły się do cyberprzestrzeni. Stały rozwój technologii teleinformatycznych łączy się z zapewnieniem bezpieczeństwa cyfrowego, które ma także wpływ na ogólne bezpieczeństwo w kraju ${ }^{5}$.

Jako ostatni problem poruszany w punkcie 2. niniejszego artykułu autorka wybrała rosnące zapotrzebowanie na żywność oraz wodę pitną. Zmieniający się klimat oraz eksplozja demograficzna, jak i brak równomiernego rozwoju gospodarczego, przyczyniają się do wzrostu popytu na żywność. W następstwie tego ceny żywności rosną, a niektóre państwa nie są w stanie zapewnić odpowiedniej ilości żywności.

\footnotetext{
3 Ibidem s. 18.

4 Ibidem s. $18-19$.

5 Ibidem s. 19.
} 
Coraz mniejsze zasoby wody pitnej, a także stałe zanieczyszczanie niektórych jej źródeł może doprowadzić do konfliktów ${ }^{6}$.

\section{Wymiar regionalny bezpieczeństwa Polski}

Według strategii z 2014 r. bezpieczeństwo Europy uzależnione zostanie od czterech czynników, które stanowią: Organizacja Traktatu Północnoatlantyckiego (NATO, ang. North Atlantic Treaty Organization), Unia Europejska (UE), stosunki z Rosją i relacje Stanów Zjednoczonych z Europą. Pomimo tego, że państwa coraz chętniej przyłączają się do organizacji międzynarodowych (NATO i UE), dalej istnieją źródła destabilizacji związane z takimi zjawiskami, jak spory o podłożu etnicznym, politycznym oraz terytorialnym. Spory takie mogą przerodzić się w konflikty zbrojne. By zapobiec konfliktom, wspólnota międzynarodowa powinna przyjąć odpowiednie rozwiązania pokojowe?.

Organizacja Traktatu Północnoatlantyckiego uznana została za (najważniejszego) gwaranta polskiego bezpieczeństwa. NATO musi dbać o utrzymanie swoich zdolności wojskowych, by móc przyczyniać się w dalszym ciągu do zbiorowej obrony oraz angażować się w inne misje. Natomiast Unia Europejska uznana została za istotny czynnik gwarantujący bezpieczeństwo w Polsce. W ramach Unii Europejskiej rozwijana jest także Wspólna Polityka Bezpieczeństwa i Obrony (WPBiO), która uzależniona jest między innymi od pogłębiania się integracji w UE, od podejmowania wspólnych działań przez UE oraz NATO oraz od chęci tworzenia zdolności obronnych. Podkreśla się także rozwój w ramach UE Przestrzeni Wolności, Bezpieczeństwa i Sprawiedliwości8.

Strategia z 2014 r. zwraca również uwagę na zmiany w kierunkach polityki zagranicznej Stanów Zjednoczonych. Zmiany te polegają na

\footnotetext{
6 Ibidem.

7 Ibidem s. 20.

8 Ibidem s. 21.
} 
Justyna Adamczyk - Bezpieczeństwo Polski...

zainteresowaniu się Azją oraz Pacyfikiem. Będą one rzutować na kształtowanie się relacji między Stanami Zjednoczonymi a Europą. Podkreśla się rolę Stanów Zjednoczonych w strukturach NATO, która ma wpłynąć pozytywnie na zapewnienie europejskiego bezpieczeństwa. Co więcej, państwa europejskie także powinny odpowiednio angażować się w relacje ze Stanami Zjednoczonymi, by osiągnąć zamierzone cele o charakterze obronnym ${ }^{9}$.

W kontekście stosunków z Rosją uwaga zostaje zwrócona na umacniającą się pozycję tego kraju oraz na jego agresywną politykę, którą potwierdzają napięte relacje z Ukrainą oraz aneksja Krymu. Polityka ta stanowi zagrożenie dla bezpieczeństwa regionalnego Polski. Sytuacja panująca w państwach będących wschodnimi sąsiadami Unii Europejskiej, a przy tym omówiona powyżej agresywna polityka Rosji, stają się wyzwaniem dla utrzymania bezpieczeństwa na kontynencie. Strategia z 2014 r. wskazuje konkretne rozwiązanie polegające na zaangażowaniu się wschodnich sąsiadów UE w proces integracji europejskiej ${ }^{10}$.

Podobnie jak w punkcie opisującym wymiar globalny bezpieczeństwa Polski, tak w punkcie 3. niniejszego artykułu, wymienia się bezpieczeństwo cybernetyczne Polski oraz wzrost jego znaczenia. Zagwarantowanie bezpieczeństwa cybernetycznego Polski zależy od polityki organizacji międzynarodowych, do których należy Polska, a także od bilateralnej współpracy z państwami członkowskimi Unii Europejskiej czy Organizacji Traktatu Północnoatlantyckiego ${ }^{11}$.

Następnym wybranym przez autorkę problemem mającym wpływ na bezpieczeństwo regionalne Polski jest starzenie się ludności europejskiej. Istotne wyzwanie stanowi przyjęcie rozwiązań dotyczących polityki migracyjnej oraz rodzinnej państw należących do Unii Europejskiej ${ }^{12}$. Autorka chciałaby także zwrócić w tym miejscu w uwagę na istotny pod względem społeczno-gospodarczym problem jakim jest

\footnotetext{
${ }^{9}$ Ibidem.

10 Ibidem s. 21-22.

11 Ibidem s. 23.

12 Ibidem.
} 
malejący przyrost naturalny w państwach europejskich. Taka sytuacja demograficzna stanowi wyzwanie dla finansów publicznych poszczególnych państw Unii Europejskiej. Unia Europejska powinna zadbać o odpowiednią politykę rodzinną oraz migracyjną państw-członków organizacji13.

\section{Wymiar lokalny bezpieczeństwa Polski}

Na początku strategia z 2014 r. wskazuje na problem demograficzny powiązany ze starzeniem się ludności (pojawił się także powyżej, w wymiarze regionalnym bezpieczeństwa Polski) oraz migracjami zarobkowymi. Konsekwencją wskazanego problemu jest brak odpowiedniej liczby pracowników, trudności w funkcjonowaniu systemu ubezpieczeń społecznych, zmiany w długości okresu aktywności zawodowej oraz zmiany odnoszące się do aktywności społecznej starszych osób ${ }^{14}$.

Co więcej jako wyzwanie (ponownie) wymieniony został terroryzm. W kontekście terroryzmu zagrożenie stanowią nie tylko pojedyncze osoby, ale także małe grupki, które w taki sposób chcą zrealizować własne cele polityczne czy ekonomiczne ${ }^{15}$.

Polska narażona jest na atak ze strony obcych służb wywiadowczych, co wiąże się między innym z posiadaniem przez nią statusu państwa członkowskiego takich organizacji międzynarodowych, jak Unia Europejska czy Organizacja Traktatu Północnoatlantyckiego. Ujawnienie informacji niejawnych mogłoby negatywnie wpłynąć na interesy Polski ${ }^{16}$.

Autorka chciałaby zwrócić także uwagę, że strategia z 2014 r. odnosi się także do gospodarczych zagadnień takich jak: korupcja, bezpieczny system finansowy, bezpieczeństwo energetyczne, konkurencyjność polskiej gospodarki, przemysł czy dekapitalizacja majątku

\footnotetext{
13 Ibidem s. 23.

14 Ibidem s. 24.

15 Ibidem s. 25.

16 Ibidem.
} 
Justyna Adamczyk - Bezpieczeństwo Polski...

narodowego. Korupcja stanowi istotne wyzwanie dla bezpieczeństwa ekonomicznego Polski. Jest ona także przeszkodą dla rozwoju państwa, natomiast bezpieczny system finansowy stanowi czynnik sprzyjający rozwojowi kraju. Wyzwaniami dla bezpieczeństwa Polski w wymiarze krajowym są bezpieczeństwo energetyczne oraz konkurencyjność gospodarki. Natomiast przemysł pomaga budować silną pozycję Polski w Europie i na świecie. Z kolei dekapitalizacja majątku narodowego może łączyć się ze wzrostem zagrożenia katastrofami technicznym ${ }^{17}$.

\section{Podsumowanie}

Strategia Bezpieczeństwa Narodowego Rzeczypospolitej Polskiej z 2014 r. charakteryzuje się podejściem systemowym, które polega na budowaniu wzajemnych relacji pomiędzy podmiotami bezpieczeństwa. Zagadnienia odnoszące się do wymiaru globalnego, regionalnego oraz krajowego przenikają się, natomiast pojęcie bezpieczeństwa jest rozumiane szeroko. Nie odnosi się już wyłącznie do spraw militarnych, lecz również do zagadnień związanych z terroryzmem, demografią, środowiskiem czy cyberkonfliktami. Podejście systemowe dało możliwość wskazania podmiotów, na których spoczywa odpowiedzialność za zrealizowanie Strategii Bezpieczeństwa Narodowego Rzeczypospolitej Polskiej z 2014 r. Do podmiotów tych zaliczyć można na przykład ministrów, wojewodów lub organy jednostek samorządu terytorialnego ${ }^{18}$.

Zdaniem autorki konstrukcja całości Strategii Bezpieczeństwa Narodowego Rzeczypospolitej Polskiej z 2014 r. stanowi przemyślane oraz przejrzyste rozwiązanie. Cały dokument liczy łącznie 57 stron, natomiast rozdział II dokumentu, który został omówiony przez autorkę, liczy 10 stron. Dla porównania autorka chciałaby wskazać, że wersja

17 Ibidem s. 25-26.

18 A. Legucka, Główne założenia Strategii Bezpieczeństwa Narodowego RP 2014, [w:] R. Kupiecki (red.), Strategie bezpieczeństwa narodowego RP. Pierwsze 25 lat, Warszawa 2015, s. 152. 
dokumentu z 2007 roku liczyła 36 stron $^{19}$. Nasuwa się w tym miejscu jeden wniosek, dotyczący zbytniej obszerności dokumentu z $2014 \mathrm{r}$. Treść rozdziału II dokumentu została ujęta w syntetyczny sposób, wymienia i opisuje w sposób skrótowy najistotniejsze z punktu bezpieczeństwa Polski zagadnienia. Odnosząc się do treści rozdziału II, autorka chciałaby zauważyć, że niektóre problemy dotyczące poszczególnych wymiarów bezpieczeństwa powtarzają się, na przykład sytuacja demograficzne i tak zwane starzenie się ludności, występują one $\mathrm{w}$ wymiarze regionalnym oraz krajowym. Zdaniem autorki w takiej sytuacji lepszym rozwiązaniem, zamiast powtarzania tej samej treści w dwóch miejscach dokumentu, byłoby zrobienie odpowiedniego odnośnika przy punkcie odnoszącym się do sytuacji demograficznej w wymiarze krajowym bezpieczeństwa, który wskazywałby na treść znajdującą się przy wymiarze regionalnym bezpieczeństwa.

\section{Bibliografia:}

Legucka A., Główne założenia Strategii Bezpieczeństwa Narodowego RP 2014, [w:] R. Kupiecki (red.), Strategie bezpieczeństwa narodowego RP. Pierwsze 25 lat, Warszawa 2015, s. 136-152.

Strategia Bezpieczeństwa Narodowego Rzeczypospolitej Polskiej z 2014 r., Warszawa 2014.

19 Ibidem, s. 136. 